\title{
OLD PARAMETERS/NEW TRICKS: THE PLACE OF CELEBRITY JOURNALISM IN PERSONA CONSTRUCTION (AND WHAT WE MIGHT DO ABOUT IT...)
}

\author{
BETHaNy USHER Newcastle University
}

Celebrity journalism is a founding discourse for the construction of persona. As the first mass-circulated media, journalism made celebrity a "very public form of discourse about the dimensions of what is public and what is private, and ultimately what is intimate" (Marshall 2014 , p. xii). It created parameters for the construction and visibility of different facets of selfidentity in public spheres (Connell 1992; Hartley 1996), which often perpetuate inequalities of social structures through offering narrow versions of self, for example against the priorities of capital (Littler 2004; Couldry 2000, 2002). This created an incessant focus on self-fulfilment through consumerism and display of consumption as if this was an accurate public reflection of who we are (Marshall 1997, 2010; deCordova 1990). As journalism naturalised and rationalised celebrity, together they created tools through which public personas became powerful cultural signifiers and props of the socio-economic and political systems in which we live. Celebrity journalism is a principal and founding characteristic of these systems, our collective understandings of self-identity within them, how we perform this to others, and the mediation of these things. As a genre, celebrity journalism ties together the contradictions of public and private dichotomies of capitalist democracies and humanises our place in it all. Journalism and celebrity helped develop the fabric of persona, establishing threads of politics and commerce, ordinary people made extraordinary through media rituals, interwoven public and private spheres, the constructions of reality and the celebration and contestation of new ideologies.

Over the past five years, I have considered the place of journalism and celebrity in persona construction across a range of different settings including mainstream celebrities (Usher 2015), politicians (Usher 2016), social media influencers or "microcelebrities" (Usher 2018a), and journalists (Usher 2019). As I did so, I became fascinated by how such dynamics formed and shifted over time, and in Journalism and Celebrity (Usher 2020) I consider how the pervasive displays and constructs of journalism and celebrity together helped to establish what persona is and means. There are two arguments from this body of work I wish to highlight here. Firstly, how an addition to Rojek's (2001) "taxonomy of fame" might help us consider the influence of the themes and construction patterns of celebrity on persona construction more broadly, including by all of us on social media. Secondly, how we might tackle cultures of attack and public shaming which jealousy guard the parameters of persona construction and display.

In a media now governed by networked constructions of reality and self-display, celebrities may still be "achieved, attributed, ascribed" (Rojek 2001), but are equally likely to be famous for having "applied" rituals of celebrification to themselves to attract attention and strategically construct persona (Usher 2018a). This dynamic reframes how we might consider how we all work, debate and socialise within worlds where clicks, shares and likes have become markers for professional and social capital. Social media offers platforms for us to demonstrate who we are and what we think to fluid audiences across personal and non-personal circles. 
'Applied' celebrity "derives from the application of longer established components, techniques and tools for building fame" (Usher 2018a, p. 185). It uses mass communications and staged authenticity to deliberately foster parasocial bonds of intimacy. As part of networked celebrity culture, this often builds and maintains self-as brand and perpetuates consumerism as if a personal liberation. For others areas of communication, such as political or journalistic, this can offer affective ways to balance authoritative voice with authentic self-display in order to engage news audiences and voters.

The term 'applied celebrity' might help us to negotiate the influence of longer established processes of communication on self-presentation. But on the other side of the exchange, representational media frenetically maintains traditional elements of power and place in public persona fame-making. Newspaper stories about public figures are shared by, at times, seemingly never-ending groups of others on social media, and as these people add opinion and comment, they make word-of-mouth an industrial-level news dissemination tool. In this process, the established processes of celebrification by news media provide powerful tools to gain attention and social traction.

For example, cultures of public shaming (in itself a process of celebrification) are derived from long-established traditions of attack journalism (Usher 2018b), and news organisations often lead moments of public trolling and 'cancel culture' across media channels and streams. Since origin in the 18th century British press and to this day, attack journalism has both social and political purposes and consequences. On one hand, the moderation of public personas links into the ideals of journalism as watchdogs of democracy and there are those who see part of this role as ensuring integrity and honesty of the famous. On the other, it can become a useful channel for maintaining hegemony over public debate and understanding of political and social norms through mixing the personal with the professional and political. At worst, persistent publication can become targeted harassment aimed specifically to cast an individual out of public spheres and this can have significant social and political impacts.

In the conclusion to Journalism and Celebrity (2020), I argue that our best hope of tackling this media malaise is via codes of media practice and regulation. For example, as a journalist I deferred to codes of practice for the British press and found many others who did so in regional and national newspapers. At present, both the Independent Press Standards Organisation (IPSO) and broadcast Ofcom codes of practice address persistent pursuit as harassment as part of 'unfair' newsgathering practices. Neither directly address abuse through persistent publication. This might be tackled through simple additions to existing clauses, and as the British Government have recently published a white paper relating to "Online Harms" (February 2020) that recommends Ofcom has additional powers to tackle social, commercial and criminal abuses which, for example, lead to trolling, change to the latter is pressing.

However, due to the fluidity of social media spaces, these changes must be international. For example, both the American Society of Professional Journalists (SPJ) code of ethics and The Australian Press Council's codes of practice directly address issues of privacy and avoidance and harm. But neither clarify that both persistent publication would equally breach their codes as persistent pursuit during newsgathering. If we understand that the power of representational media in social space is multifaceted - and that without tackling one area of culture that causes similar social harm we cannot correct others - then we might be best placed to navigate, negotiate and identify the ways media regulation needs to change. In light of the complex networked media ecosystems that now support the construction of persona across multifaceted layers of personal, social, public, professional, political and capital, we must better grasp the power dynamics at play. But we also must find tools to help steer cultures that are conducive to 
open and honest self-display, less linked to consumer based capital, and which have mechanisms in place to tackle persona(l) attack.

\section{WORKS CITED}

Connell, I 1992, 'Personalities in the Popular Media', in P Dalghren and C Sparks (eds) Journalism and Popular Culture, London, Sage, pp. 64-84.

Couldry, N 2000, Inside Culture, London, Sage.

Couldry, N 2002, 'Playing for Celebrity: Big Brother as a Ritual Event', Television and New Media, vol. 3, no. 3, pp. 295-310.

deCordova, R 1990, Picture Personalities: The Emergence of the Star System in America, Urbana, IL, University of Illinois Press.

Hartley, J 1996 Popular Reality: Journalism, Modernity, Popular Culture, London, Arnold.

Marshall, PD 2014, 'Celebrity in the Digital Era: A New Public Intimacy', in Celebrity and Power, 2nd edn, Minneapolis, University of Minnesota Press.

Littler, J 2004, 'Celebrity and 'Meritocracy', Soundings: A Journal for Politics and Culture, vol. 26, pp. 118-130.

Usher, B 2020, Journalism and Celebrity, Routledge, London.

Usher, B 2019, 'The Celebrified Columnist and the Opinion Spectacle: Production, Performance and Purpose', Journalism Studies, Online, https://doi.org/10.1177/1464884919897815.

Usher, B 2018a, 'Rethinking Microcelebrity: Key Points in Practice, Performance and Purpose', Celebrity Studies, vol. 11, no. 2, pp 171-188.

Usher, B. (ed) 2018b, The State of the Media, Byline Media, London.

Usher, B 2016, 'ME, YOU, and US: Constructing Political Persona on Social Networks during the 2015 UK General Election', Persona Studies vol. 2, no. 2, pp. 19-41.

Usher, B 2015, 'Twitter and the Celebrity Interview', Celebrity Studies, vol. 6, no. 3, pp. 306-21. 